\title{
2433 局所乾燥下での皮膚の非侵襲計測
}

\section{Non-invasive measurement of the skin under the local drying condition}

\author{
（煙山健仁（芝浦工大） \\ 山本紳一郎（芝浦工大） \\ 中野敬生（芝浦工大） 正 \\ 舟久保熙康（芝浦工大）
米田隆志（芝浦工大）正 小山浩幸（芝浦工大） 田上八朗 (東北大)

Takehito KEMURIYAMA, Takao NAKANO, Takashi KOMEDA, Hiroyuki KOYAMA, Shin-ichiroh YAMAMOTO, Hiroyasu FUNAKUBO, Shibaura Institute of Technology, 307 Fukasaku, Saitama Hachiro TAGAMI, Tohoku University

Key words : Drying Condition, Skin Hardness, Water Content, Atopic Dermatitis

1.はじめに

現在、皮膚の疾患は社会的な問題となっており、高齢者 層では老人性乾皮症のような老化による様々な皮单疾患が 頻発し、若年者層では生活環境に皮庿が過敏に反応するア トピー性皮虐炎が急増している。アトピー性皮虙炎や老人 性乾皮症は、温度変化や湿度変化などの環境変化によって も詳みが発症するといわれ、これまでに角層水分量を変化 させた角層水和実験によって健常者とアトピ一性皮膚炎者 の水分量変化と皮膚硬さ変化について報告してきた 1 。

本報告では温度や湿度などの環境変化に着目し、局所的 に皮膚を $15 \%$ 以下の乾燥状態にしたときの皮庿性状を非 侵襲に計測し、環境変化に対する皮膚举動を比較すること を目的とした。今回は、皮䖉の非侵襲計測として角層水分 量、皮膚硬さを計測した。

\section{2. 方法}

対象は 20 代の健常者とアトピー性皮虐炎者で、合計 10 名とした。測定部位は前腕屈側中央部とし、皮膚硬さの計 測は乎関節部を固定して行なった。計測は恒温恒湿室内で 行ない、温度 $23^{\circ} \mathrm{C}$ 、湿度 $30 \%$ に設定した。

局所的な乾燥状態は被験者の前腕部をグローブバックで 覆い、内部に窒素ガスを注入することでグローブバック内 の湿度を $15 \%$ 以下とした。このとき、角層水分量と皮虐硬 さの計測プローブをグローブバック内に挿入し、乾燥 10 分後に皮膚を非侵襲に計測した。

角層水分量の計測には静電容量測定法を用いた Corneometer CM820（C+K 社製）を、皮膚硬さの計測に はVenustron（AXIOM 社製）を使用した。Venustronは 物質の音響インピーダンスの違いから求めた周波数変化量 と押し込み荷重から皮膚硬さの評価ができる ${ }^{2)}$ 。計測プロ 一ブは触覚センサ、荷重センサ、および変位センサで構成 され、直径は $4 \mathrm{~mm}$ である。プローブの動作は $57 \mathrm{kHz}$ で振 動しながら皮膚を押し込み、押し込み荷重、変位と周波数 変化量を計測する。押し込み速度は $3 \mathrm{~mm} / \mathrm{sec}$ 、押し込み深 さは $3 \mathrm{~mm}$ に設定した。

\section{3. 結果}

局所的に皮膚を乾燥させたときの角層水分量、押し込み 荷重と周波数変化量の代表例を図 1 から図 3 に示す。図 1 は男性健常皮膚、図 2 は女性煡常皮膚、図 3 は男性アトピ
一性皮膚の計測結果である。押し込み荷重曲線と周波数変 化量曲線はヒステリシスカーブとなり、下側が戻り過程を 示している。

局所的に乾燥させた 10 分後の皮单は、通常時に比べて 静電容量測定法を用いた角層水分量は変化しなかった。

局所乾燥 10 分後の皮膚は、通常時に比べて皮膚押し込 み荷重は増加した。周波数変化量は変わらなかった。

男性健常皮廉、女性健常皮膚、アトピ一性皮膚を比較す ると、皮唐押し込み荷重は女性皮膚より男性皮膚が大きい 傾向があった。

物質の音響インピーダンスの違いから求めた周波数変化 量は減少するほど皮庿がやわらかく、周波数変化量が変わ らないと皮虚が硬いと考えられる ${ }^{2)}$ 。周波数変化量を比較 すると男性健常皮膚、女性健常皮膚、アトピ一性皮膚の順 でアトピー性皮膚が硬い傾向にあった。

男性健常皮膚は、押し込み荷重を指標とすると女性健常 皮膚より硬く、周波数変化量を指標とすると女性健常皮䖒 よりやわらかいことが示された。

\section{4. 考察}

局所的に皮膚を乾燥させた場合、角層の水分が蒸散する ため角層水分量は変化すると考えていたが、角層水分量は 変化しなかった。今回使用した角層水分量計は静電容量測 定法を用いており、角層表面ではなく、さらに深部を計測 する可能性がある。このため、10 分間乾燥では角層水分量 に変化があらわれなかったと考えられる。

局所乾燥後の皮膚押し込み荷重に違いがあらわれた。こ の現象は角層の水分が减少したことで皮虚が硬くなったと 考えられ、角層水分量は変化しなかったが角層の水分は 10 分間乾燥によって蒸散したことが示唆される。

男性健常皮䖒とアトピー性皮膚を比較すると、周波数変 化量に差があらわれた。周波数変化量は物質によって減少 率が変わるため、男性健常皮膚とアトピー性皮虐では皮虚 の構成物質の割合が異なると考えられる。アトピ一性皮膚 のような乾燥皮唐は表皮由来の脂質であるセラミドが减少 していることが報告されており3)、このことを非侵襲に計 測できることが示唆された。また、男性健常皮膚と女性健 常皮庙においても周波数変化量が異なることから、プロー ブ先端部と皮䖒表面の張力や摩擦などの関倸が周波数変化 量に影響を与える可能性も示唆された。

日本機械学会〔No.02-04〕第14回バイオエンジニアリング講演会講演論文集('02.3.5～6 東京) 

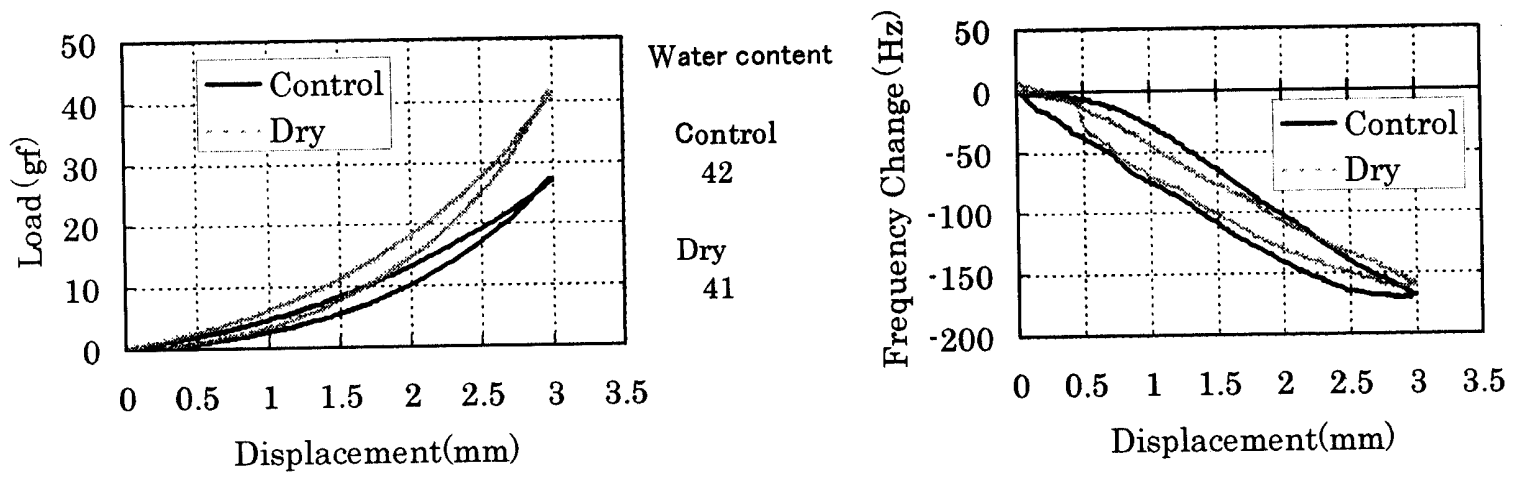

Fig.1 Load-displacement curve and frequency change-displacement curve of healthy skin (male)

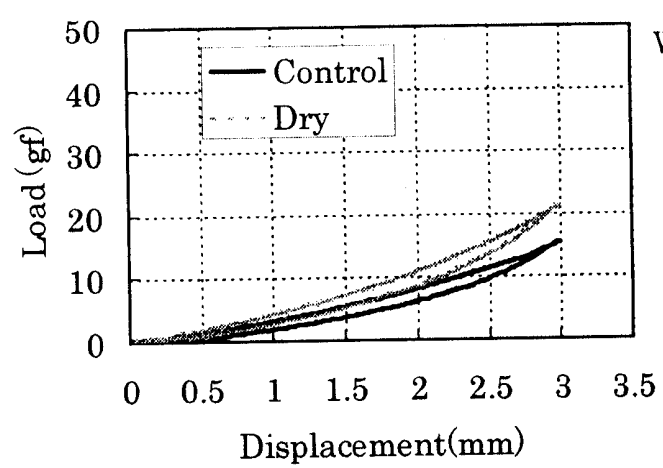

Water content
Control
25
Dry
24

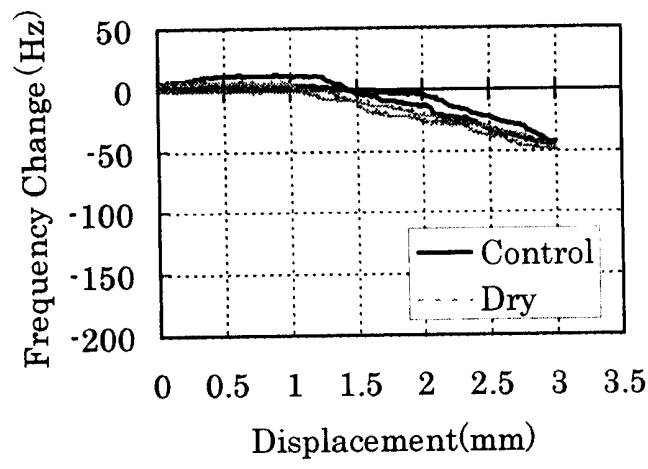

Fig.2 Load-displacement curve and frequency change-displacement curve of healthy skin (female)
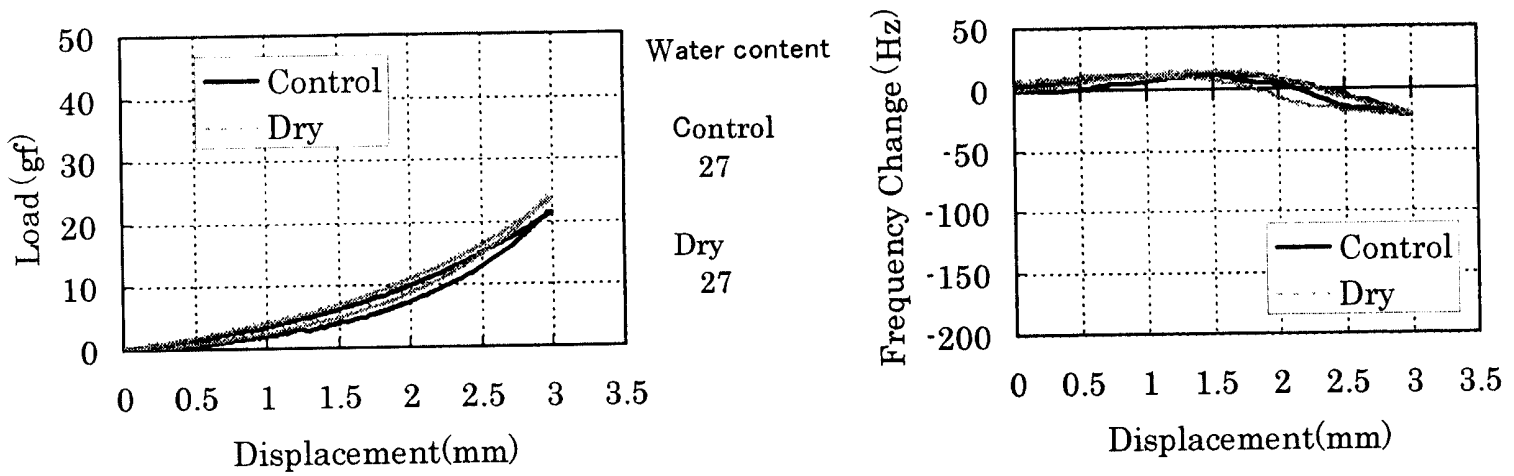

Fig.3 Load-displacement curve and frequency change-displacement curve of atopic skin (male)

5.まとめ

局所的に湿度を $15 \%$ 以下に低下さぜたときの皮虙挙動 を非侵襲に計測する手法を考案し、静電容量測定法による

角層水分量、皮膚押し込み荷重、音響インピーダンスの違 いから求めた周波数変化量を計測した。

角層水分量は乾燥 10 分によって変化しなかったが、皮 膚押し込み荷重が大きくなり、皮膚は局所的な乾燥によっ て硬くなることが示された。

男性健常皮虐とアトピ一性皮膚で周波数変化量が異なる ここが示され、周波数変化量を指標と寸ることで角層の脂 質の減少を非侵襲に計測できる可能性が示唆された。

\section{謝辞}

本研究の一部は文部科学省科学技術振興調整費「日常生 活においてひふを守る総合研究」ならびに NEDO 産業技 術フェローシップ事業によった。

\section{参考文献}

1）小山浩幸、米田隆志ほか：皮膚の角層水分量と硬さの 計測に関寸る研究 (第 2 報), 日本機械学会第 13 回バ イオエンジニアリング講演会論文集, 218/219 (2001)

2）尾股定夫、本岡則幸ほか：皮虙硬化度測定の進歩, 自 己免疫疾患の臨床，157/165（1998）

3）芋川玄爾 : 湿疹・皮膚炎群に対する外用剤の基礎と臨 床，日本臨床皮膚科医学会雑誌，87/96（1998） 